\title{
Integration of Statistical Models and Computer Simulation in Environmental Accidents: A Study on Leakage of Red Mud in the Pará River, Amazon, Brazil
}

\author{
Pedro M. de Sousa Jr., ${ }^{\circledR *, a}$ Simone F. P. Pereira, ${ }^{b}$ Ronaldo M. Rocha, ${ }^{c}$ \\ Mateus H. D. Alves, ${ }^{\oplus a}$ Luciana S. Pinheiro, ${ }^{a}$ Daniel P. Nogueira, ${ }^{b}$ \\ Orivan M. M. Teixeira ${ }^{d}$ and Auriane C. S. Gonçalves ${ }^{d}$
} ${ }^{a}$ Departamento de Engenharia e Meio Ambiente, Universidade Federal Rural da Amazônia,
68700-665 Capanema-PA, Brazil

${ }^{b}$ Laboratório de Química Analítica e Ambiental, Instituto de Ciências Exatas e Naturais, Universidade Federal do Pará, 66075-110 Belém-PA, Brazil

${ }^{c}$ Laboratório Central, Secretaria de Estado de Saúde, 66823-010 Belém-PA, Brazil

${ }^{d}$ Empresa Brasileira de Pesquisa Agropecuária-Amazônia Oriental, 66095-903 Belém-PA, Brazil

\begin{abstract}
The introduction of potentially toxic elements (PTEs) from industrial activities in water bodies, highlights the vulnerability of the environment and the need for actions focused on the implementation of mechanisms that help in the control and remediation of these impacts. The objective of the study was based on the integration of instrumental analytical methods, multivariate statistics, and computer simulation models, with the proposal of implementing realistic scenarios of the red mud plume behavior in the Pará River. The selected location was the municipality of Barcarena-PA, where is located an important alumina/aluminum industrial center. With the aid of the inductively coupled plasma optical emission spectrometer (ICP OES), the chemical elements $\mathrm{Al}, \mathrm{B}, \mathrm{Cr}, \mathrm{Fe}, \mathrm{Mn}, \mathrm{P}, \mathrm{Ti}$, and $\mathrm{Zn}$ were quantified and the principal component analysis (PCA) allowed to select $\mathrm{Al}, \mathrm{B}, \mathrm{Fe}, \mathrm{P}$, and $\mathrm{Zn}$ as the most relevant with $98.68 \%$ of the accumulated variance. Some scenarios were proposed by the simulated hydrodynamic model, which evidenced that the Trambioca community would be the most affected in the first $13 \mathrm{~h}$ after the effluent overflowed, and the other locations in domino effect. The main scientific gain of the proposal is the possibility of the predictive scenarios to help the actions of containment and mitigation of environmental damages by public control agencies, institutions involved, and other competent bodies.
\end{abstract}

Keywords: multivariate, hydrodynamic models, chemical elements

\section{Introduction}

In recent decades, an increasing focus on impacts from mining and its consequences for the ecosystem has been in place, particularly concerning the extraction and processing of bauxite, the raw material for aluminum. Mineral exploration generates a political, social, and economic paradigm, as promotes environmental impacts, but also drives the economy in several countries. ${ }^{1}$ Bingöl et al. ${ }^{2}$ already emphasized this situation when reporting environmental liabilities caused to soil, air, and water in the Dilovas district in Kocaeli, Turkia, by 185 companies in the metal industry. Gomes et al. ${ }^{3}$ and Bhardwaj et al. ${ }^{4}$ corroborate that this model, in countries like Cameroon,

*e-mail: pedromsj@ hotmail.com for example, is an activity rooted in the local culture, although this process brings a decline in the quality of natural resources due to the addition of potentially toxic elements (PTEs) indiscriminately. ${ }^{5}$

In the Brazilian Amazon region, the city of Barcarena is a classic example of this economic model of exploration based on the transformation industry, which started in the 1980 and still stands out as the main hub for processing bauxite for alumina production, using Bayer process and metallic aluminum. ${ }^{6}$ The verticalization of the local economy has brought improvements for the population from the social and economic point of view, although the environmental liabilities for the region are more striking than the benefits. ${ }^{7}$

The main factor associated with environmental problems is due to the waste coming from the production 
process of alumina (red mud), which consists of $\mathrm{As}, \mathrm{Pb}$, $\mathrm{Hg}, \mathrm{Cd}, \mathrm{Ni}, \mathrm{Zn}$, and $\mathrm{Cu}$, considered PTEs and bring great dangers to the environment and human beings, such as the event that took place in the city of Ajka in Hungary in October 2010, where containment tanks overflowed and the slag hit the rivers of the locality causing serious problems to the environment and consequently to the residents, as cited by Zacháry et al. ${ }^{8}$ and corroborated by Arifin et al. ${ }^{9}$

In an overflow situation, a large volume of these PTEs can reach the water bodies, promoting numerous chemical, physical, and biological changes in local ecosystems, making the remediation process more complex and costly. Several researchers ${ }^{8-10}$ report in their work in similar areas, that due to the diversity of toxic substances, there is a need to increasingly use efficient methods and methodologies to explain and portray the impacts caused mainly to terrestrial and water ecosystems.

In situations of this magnitude, it is common to use hydrodynamic models of pollution plumes, factorial analysis of principal components, or even remote sensing of prediction to explain the main impacts caused. However, the limiting factors of each technique are not taken into account, which may vary from the number of samples, in the case of statistics, hydrodynamic data, historical series, and satellite images suitable for predictive maps, as advocated by Hou et al. ${ }^{11}$

Based on this type of analysis, authors like Jha et al., ${ }^{12}$ Singh et al. ${ }^{13}$ and Tonhá et al., ${ }^{14}$ agree that the integration of techniques allows better interpretation of the data, as well as the easing of the limitations of the methods, evidenced when worked independently.

Some authors show that the proposal for models employment is more and more recurrent, in addition to explaining the number of possibilities that it provides, as is the case of Bodrud-Doza et al., ${ }^{15}$ when integrating multivariate statistical and geostatistical techniques in the characterization of drinking water quality in Bangladesh. Islam et al. ${ }^{16}$ applied this proposal in the assessment of surface water quality and its sustainability in the district of Joypurhat, Bangladesh, integrating mapping and geographic information systems (GIS) technique and multivariate statistics as mentioned by Periáñez ${ }^{17}$ who researched the influence of the pollution plume of the Rhône River in marine benthic ecosystem integrating descriptive ecology and predictive modeling.

Oprea $^{18}$ emphasizes the importance and necessity of using diversified qualitative and quantitative analytical techniques in an attempt to deal with increasingly complex and specific environmental problems. Therefore, the possibility of connecting hydrodynamic modeling and multivariate statistics to improve analytical results of an environmental nature, such as the prediction of PTE behavior in natural environments, becomes of great value since one approach can reveal the behavior of chemical elements in the environment and the other technique provides a selection of the most relevant variables.

In this aspect, the present study proposes the association of instrumental analytical techniques, multivariate statistical methods, and hydrodynamic plume models as a tool for prediction and support in the occurrence of environmental disasters. The overflow situation in the red mud basin that occurred in 2018 in the city of Barcarena, in the Brazilian Amazon region of Brazil, will be used as a model.

\section{Experimental}

Characterization of the study area: Barcarena industrial complex

Barcarena is the main city of this complex due to its strategic location on the banks of the Pará River. Pereira et $a l .{ }^{19}$ report that the city is experiencing a socioeconomic paradox, on the one hand, the economy with great financial values involved in the extraction, processing, and commercialization of products from this activity, and on the other, the local population living with problems related to industrial liabilities and with sanitation (landfills, domestic and sanitary effluents), health and housing issues.

The main problem in the region is the recurring environmental impacts in the Barcarena Industrial Complex, such as the disaster called the Spillage of Chemicals in Lacustrine, Fluvial, Marine, and Aquiferous Environments, due to the overflow of the Imarys and Hydro tailings dams that occurred in $2015 .{ }^{20}$ In 2018, an incident of the same proportion occurred again, pointing out the vulnerability of the region and the risks that the population and local ecosystems are subject to due to the overflow and irregular release of industrial effluents in the city of Barcarena. ${ }^{21}$

\section{Campaigns and sampling}

In the collection procedure, a boat was employed to travel the Pará River at ten (10) predetermined points. The campaigns took place monthly, using Amazonian seasonality and alternating syzygy tides and quadrature as a comparative parameter, in which the rainy (January to June) and low-rainy (July to December) periods stand out. ${ }^{22}$

The samples were collected in duplicates according to standard methods and the collection sites were properly georeferenced using the global positioning system (GPS). ${ }^{22-25}$ The research location and the sampled space with the identified collection points are shown in Figure 1. 


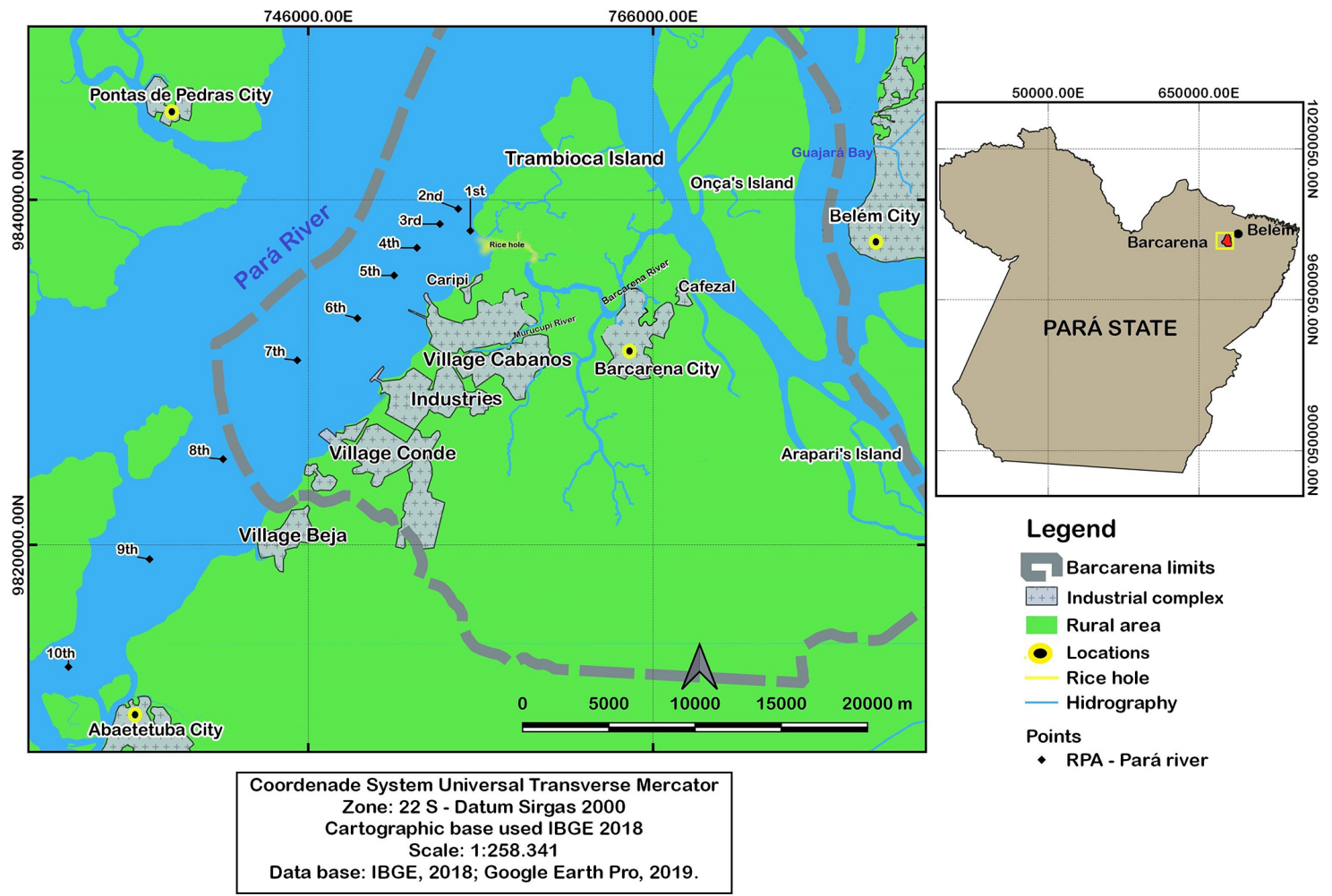

Figure 1. Image of the Barcarena industrial complex and the respective sample points.

Considering the hydrodynamic characteristics of the rivers, the "Van Dorn" bottle model (volume of 5 liters) was adopted for collection in the superficial layers (equal to $100 \%$ of solar irradiation). The $500 \mathrm{~mL}$ polyethylene bottles, previously decontaminated, were packaged and kept refrigerated at $4{ }^{\circ} \mathrm{C} .{ }^{26}$

The samples were filtered with $0.45 \mu \mathrm{m}$ pore size membranes to extract the dissolved content. To guarantee the quality of the analytical results, after filtration the samples were acidified with $\mathrm{HNO}_{3} 1: 1$ in order to guarantee adsorption processes between the solution and the flask, as recommended by the National Guide for the Collection and Preservation of Samples of the National Water Agency ${ }^{27}$ and standard methods for the examination of water and wastewater. ${ }^{26}$

\section{Analytical determination of samples}

The technique used in the determination of the chemical elements $\mathrm{Al}(\lambda=306.22 \mathrm{~nm}), \mathrm{B}(\lambda=317.93 \mathrm{~nm})$, $\mathrm{Cr}(\lambda=267.72 \mathrm{~nm})$, Fe $(\lambda=238.86 \mathrm{~nm})$, $\operatorname{Mn}(\lambda=278.30 \mathrm{~nm}), \mathrm{P}(\lambda=253.60 \mathrm{~nm}), \operatorname{Ti}(\lambda=334.94 \mathrm{~nm})$ and $\mathrm{Zn}(\lambda=213.86 \mathrm{~nm})$ was the inductively coupled plasma optical emission spectrometry (ICP OES), as it is more sensitive, with low limits of detection, and, mainly, able to provide the multi-element analysis. ${ }^{27}$ The equipment used to quantify the elements is from the Varian brand and the Vista
Pro model (Mulgrave, Australia) and the other adjustments for better performance of the equipment were based on the manufacturer's instruction manual. ${ }^{8,28}$

\section{Quality control of the methodology}

The accuracy check was performed with analysis of the standard river water reference material (SRM 1640a NIST) as suggested by the EPA Standard Methods 6010 B. ${ }^{29}$ In general, results were in the acceptable range (90 to 100\%) for the recovery of $\mathrm{Al}, \mathrm{B}, \mathrm{Cr}, \mathrm{Fe}, \mathrm{Mn}, \mathrm{P}, \mathrm{Ti}$, and $\mathrm{Zn}$, was forwarded to the Laboratório de Química Analítica e Ambiental (LAQUANAM). The determined results are shown in Table 1.

\section{Data treatment and interpretation}

In data treatment, the $\operatorname{SPSS}^{\circledR}$ Statistical 21 was used to minimize systematic errors and obtain accurate results. ${ }^{30}$ For this, univariate and multivariate statistical methods were employed, such as principal component analysis (PCA) to select and group variables in the condition that the highest percentage of relevant information about the data set is contained..$^{31,32}$ The motivation for using this technique is based on previous studies, ${ }^{2,33,34}$ that argue that the multivariate statistical technique is more widespread due to the importance of multidimensional measurements 
Table 1. Analytic quality control for chemical elements analysis in sample water $(n=10)$

\begin{tabular}{|c|c|c|c|c|c|}
\hline Element & $\mathrm{LOD}^{\mathrm{a}} /\left(\mathrm{mg} \mathrm{L}^{-1}\right)$ & $\mathrm{LOQ}^{\mathrm{b}} /\left(\mathrm{mg} \mathrm{L}^{-1}\right)$ & SRM-1640a $a^{c} /\left(\mathrm{mg} \mathrm{L}^{-1}\right)$ & Average / $\left(\mathrm{mg} \mathrm{L}^{-1}\right)$ & Recovery /\% \\
\hline$\overline{\mathrm{Al}}$ & 0.0021 & 0.0074 & $0.0530 \pm 0.0018$ & 0.0526 & 99.221 \\
\hline $\mathrm{B}$ & 0.0161 & 0.0532 & $0.3030 \pm 0.0031$ & 0.2892 & 95.443 \\
\hline $\mathrm{Cr}$ & 0.0010 & 0.0033 & $0.0400 \pm 0.0003$ & 0.0397 & 99.276 \\
\hline $\mathrm{Fe}$ & 0.0053 & 0.0161 & $0.0360 \pm 0.0018$ & 0.0324 & 90.008 \\
\hline Mn & 0.0082 & 0.0280 & $0.0400 \pm 0.0003$ & 0.0384 & 96.112 \\
\hline $\mathrm{P}^{\mathrm{d}}$ & 0.0142 & 0.0131 & $0.0630 \pm 0.0019$ & 0.063 & 100.000 \\
\hline $\mathrm{Ti}^{\mathrm{d}}$ & 0.0010 & 0.0042 & $0.0040 \pm 0.0011$ & 0.0037 & 92.447 \\
\hline$\underline{\mathrm{Zn}}$ & 0.0050 & 0.0160 & $0.0550 \pm 0.0004$ & 0.0525 & 95.465 \\
\hline
\end{tabular}

a Limit of detection ((LOD = 3 RSD/a) RSD = relative standard deviation) for 10 measures of the blank, a: slope analytical curve; blimit of quantification $(\mathrm{LOQ}=10 \mathrm{RSD} / \mathrm{a}) ;{ }^{\mathrm{c} C e r t i f i e d ~ R e f e r e n c e ~ M a t e r i a l s ~ t r a c e a b l e ~ t o ~ N I S T(1640 a) ; ~}{ }^{\mathrm{d}}$ method of standard addition.

in the chemical area. They also consider it to be a technique that most significantly alters the view of chemical data analysis, justifying its relevance.

To obtain more consistent answers, researchers ${ }^{35-37}$ suggest previous treatment of the data matrix through standardization by $\mathrm{Z}$ scores. As for factor analysis, the raw data matrix was used in the analysis of main components, without any rotation, to preserve the natural condition of the variables.

To explain the results, a set of widely recognized statistical techniques applied to the selection of variables will be presented, among them, the PCA stands out. Its importance in research refers to the possibility of identifying, in a complex sample set, the metals with greater relevance and chemical influence in the studied environment, enabling a more careful and reliable analysis of the studied area. ${ }^{38-41}$

Based on research, ${ }^{42-46}$ it was identified that the parameters used in modeling are predetermined without statistical appeal. What is intended is to present an analytical model for explaining environmental impacts using statistical mathematical models and computer simulation.

\section{Hydrodynamic modeling}

The computational hydrodynamic modeling was implemented with the help of the Base System of Environmental Hydrodynamics, SisBaHiA ${ }^{\circledast .47}$ The system was provided free and is registered by the Coppetec Foundation on behalf of COPPE/UFRJ. Following the methodological pattern, ${ }^{48}$ for spatial discretization of the worked mesh domain, the presence of 133 elements was established and 647 nodes were constructed with quadrangular elements, facilitating the refining of the regions close to the source.

Yang et al ${ }^{49}$ complement the importance of the domain description in the research. The domain was built from the image referring to the complex of the bay of Marajó, which includes the Barcarena, Pará and Guamá rivers, present in the nautical chart No. 304 acquired from the Directory of Hydrography and Navigation of the Brazilian Navy, from where the bathymetry data were also obtained. ${ }^{50}$

As for the harmonic constants used, they are contained in letter 55 of the tide stations acquired from the Fundação de Estudos do Mar (FEMAR). ${ }^{51}$ Figure 2 shows the result of the hydrodynamic model, in which Figure 2a illustrates the discretized domain and Figure $2 b$ the bathymetric.

\section{Pollution plume modeling}

To model the dispersion of pollutants, the parameters were selected from the results of the principal component analysis (PCA). The chemical elements were evaluated for their average content and toxic potential as recommended by CONAMA resolution No. 357/2005, ${ }^{52}$ to define the limits established in the plume hydrodynamic model. In this study, an extreme impact condition was admitted, when the determined values are above the limits established by the regulations.

Graham et al. ${ }^{53}$ highlight the importance of the water body natural conditions for the simulation. Referring to the aforementioned theme, the study admitted sediments of the fine sand class and thus the value of $0.05 \mathrm{~m}$ was adopted for the equivalent bottom roughness and sandy bed with sediment transport. ${ }^{54}$

Regarding the tidal component, a hydrodynamic circulation model was admitted in which it acts as a forcing due to the study being focused on the estuarine region where it exerts great influence. The time series of water level rise due to the astronomical tide adopted in this study corresponds to records obtained in the Catalog of Brazilian Tidal Stations of (FEMAR), ${ }^{51}$ for the Port of Belém. For simulation, it was conditioned that the value of surface elevation in the instant $0 \mathrm{~s}$ would be 2,321 $\mathrm{m}$ (information provided by the Observatory of the Amazon Coast $)^{55}$ with a $60 \mathrm{~s}$ time interval, in a time interval between 12600.000 to $2598000.000 \mathrm{~s}$ corresponding to 30 days, corroborating with a similar condition proposed by Graham et al. ${ }^{53}$ 


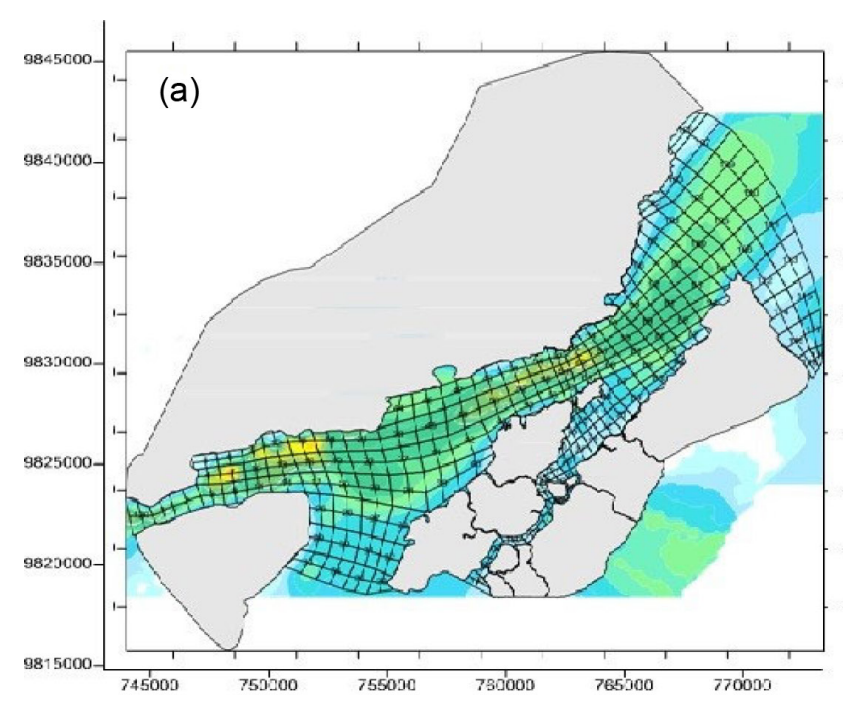

Figure 2. Discretized and bathymetric domain of the proposed model.

\section{Transport analysis}

The objective of the transport analysis was to show the direction of the stain or plume of the contaminants in which this work proposes to simulate. For this model, an instantaneous release of the red mud residue was estimated at a pre-defined point located at the mouth of the Furo do Arrozal, the confluence between the Pará and Barcarena rivers, to observe the dispersion pattern of contaminants and pollutants along the modeled area (Pará River).

The site was chosen because Furo do Arrozal is the main connection to the Murucupi and Barcarena rivers, which have been greatly affected by overflowing red mud basins over the years.

Despite the difficulty in providing information on the flow of the Marajó complex, for this simulation, a flow of $41.640 \mathrm{~m}^{3}$ of water was adopted for the Pará River, the main river in the studied domain, based on data provided by the Physical Oceanography Laboratory of the Geosciences Institute of the Federal University of Pará.

\section{Validation of tidal circulation}

Validation is the main step in modeling, as the hydrodynamic simulation will only become reliable if the results are in accordance with the observed data. To avoid errors associated with the modeling process, the comparison between the observed nodal velocity module was used as a validation factor, which was provided by the Physical Oceanography Laboratory of the Geosciences Institute of the Federal University of Pará.

These unpublished data were collected throughout $13 \mathrm{~h}$ in syzygy tide with the aid of equipment ADCP (acoustic doppler current profilers), by Teledyne RD Instruments,

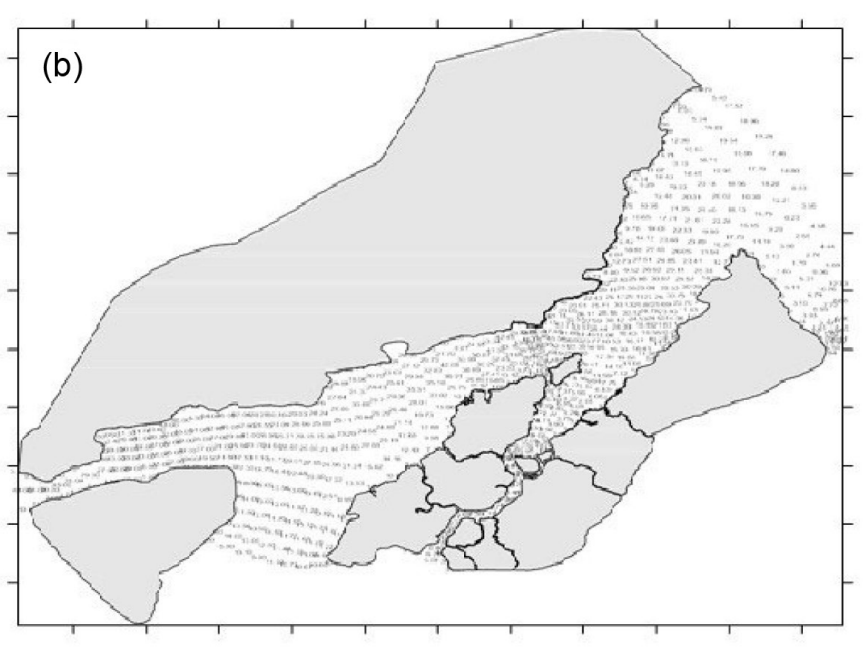

model Workhorse Rio Grande (Camino Dos Rios Thousand Oaks, USA) with a frequency of $600 \mathrm{~Hz}$ and the module of virtual nodal speed, generated from the implementation of the hydrodynamic model for the study area. It is worth mentioning that the validation method adopted in the study is linked to the comparison between the minimum and maximum values of the observed and virtual nodal speed in the mean temporal interval, in which the model finds more stable oscillation. Figures 3 and 4 show the observed and virtual speed modules.

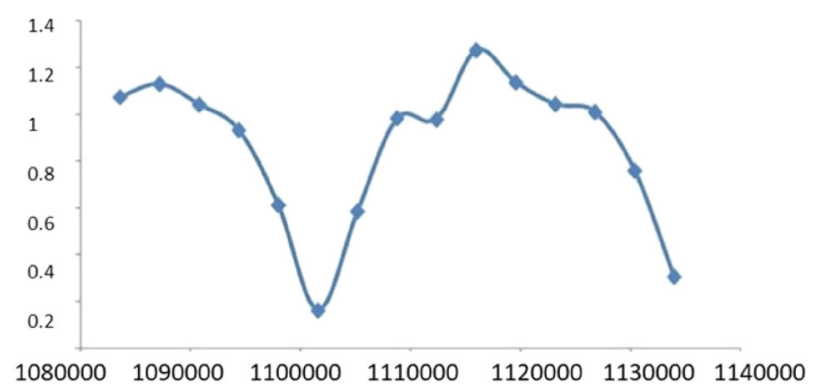

Figure 3. Graph of the oscillation pattern of the real nodal velocity as a function of time.

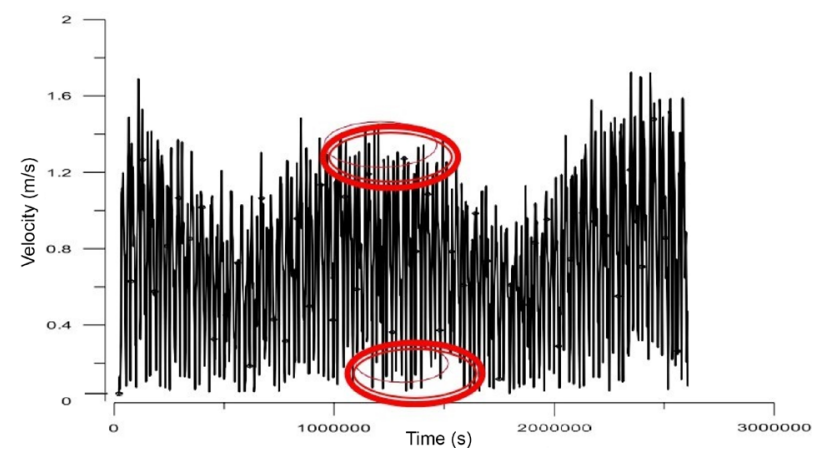

Figure 4. Graph of the oscillation pattern of the virtual nodal velocity as a function of time. 


\section{Results and Discussion}

In this step, the results of the integration of statistical techniques and simulation models will be presented and discussed. To ensure the efficiency and robustness of the results it is necessary to establish which criteria were used in the research. Regarding the statistical treatment, the profile of the data matrix was previously evaluated, and adopting concepts and suggestions from authors such as Harrar et al. ${ }^{56}$ and Horváth et al.,$^{57}$ it was implemented the normality test and from the results, it was found that the set presents a normal distribution $\rho>0.05$, using as verifier parameter the Shapiro-Wilk test, as suggested by Rachdi et al. ${ }^{58}$

\section{Descriptive statistics}

Table 2 presents the results of the descriptive statistics of the analyzed parameters. The results were analyzed according to CONAMA resolution No. 357/05, 52 and it was found non-conformity for the average values of parameters $\mathrm{Al}, \mathrm{B}, \mathrm{Fe}, \mathrm{P}$, and $\mathrm{Zn}$.

All elements present an important variability when the minimum and maximum values are analyzed, which was later proven by the standard deviation. Such information conditions the interpretation that they present heterogeneous behavior in the water body, suggesting that chemical transformations are occurring, forming new potentially insoluble compounds along the river, justifying the reduction of the contents in the water surface region over time.

This behavior could be a natural situation, however, when evaluating the average concentration values it is identified that this condition has an anthropic character, since they are part of the composition of the red mud tailings and are not components of the geochemistry of the region. ${ }^{59}$
Al correlates with aggravations to neurological diseases, more specifically to Alzheimer's disease and sclerosis, likewise, there are discussions about the influence of manganese and Fe on Parkinson's disease when ingestion occurs through potable water. ${ }^{60,61}$ Most $\mathrm{Al}$ salts are characterized by high insolubility, in a $\mathrm{pH}$ range between 6 and 8 . Solubility is achieved under acidic $(\mathrm{pH}<6)$ or alkaline $(\mathrm{pH}>8)$ conditions, which reflects its amphoteric nature. ${ }^{62}$ D'Haese et al. ${ }^{63}$ add that this metal becomes toxic to animals and fish, for example, the situation is impaired when the $\mathrm{pH}$ of the aquatic environment is below 6 .

As for $\mathrm{P}$, the natural aquatic environment favors the presence of larger ions that form stable phases with $\mathrm{P}$, especially $\mathrm{Ca}^{2+}, \mathrm{Fe}^{2+}$, and $\mathrm{Al}^{3+}$. From the environmental point of view, the results indicate the presence of nutrients such as $\mathrm{Fe}$ and $\mathrm{P}$, which help in the nutrition of the entire ecosystem. The presence of soluble phosphate must not be controlled by $\mathrm{Ca}^{2+}$, unless there is an excess of $\mathrm{Ca}^{2+}$ in carbonate sediments. ${ }^{64}$

The most appropriate hypothesis for the behavior of $\mathrm{P}$ is described by authors, ${ }^{65,66}$ when they infer that the increase in temperature favors phosphate adsorption in sediments in the aquatic environment. Aligned with the idea, Tang et al. ${ }^{67}$ report that biological activity has an important role in the transport of $\mathrm{P}$ since high temperatures can increase biological activities that consume phosphate, leading to a lower concentration of phosphate in the water column and promoting the desorption of $\mathrm{P}$ in the sediment.

The thesis defended by the authors corroborates the condition of the researched area in the following aspects: the first is related to the geographical location of the city of Barcarena, close to the equator with a hot and humid tropical climate with an average temperature of $32{ }^{\circ} \mathrm{C} ; 68$ the second aspect can be observed by the statistical values of minimum $\left(0.02 \mathrm{mg} \mathrm{L}^{-1}\right)$ and maximum $\left(14.57 \mathrm{mg} \mathrm{L}^{-1}\right)$

Table 2. Descriptive statistics of the variables in the study set

\begin{tabular}{lccccc}
\hline Element / $\left(\mathrm{mg} \mathrm{L}^{-1}\right)$ & $\begin{array}{c}\text { CONAMA 357/05 / } \\
\left(\mathrm{mg} \mathrm{L}^{-1}\right)\end{array}$ & $\begin{array}{c}\text { Average / } \\
\left(\mathrm{mg} \mathrm{L}^{-1}\right)\end{array}$ & $\begin{array}{c}\text { Standard deviation / } \\
\left(\mathrm{mg} \mathrm{L}^{-1}\right)\end{array}$ & $\begin{array}{c}\text { Minimum / } \\
\left(\mathrm{mg} \mathrm{L}^{-1}\right)\end{array}$ & $\begin{array}{c}\text { Maximum / } \\
\left(\mathrm{mg} \mathrm{L}^{-1}\right)\end{array}$ \\
\hline $\mathrm{Al}$ & $<0.1$ & 0.196 & 0.480 & 0.030 & 2.620 \\
$\mathrm{~B}$ & $<0.5$ & 0.146 & 0.090 & 0.030 & 0.630 \\
$\mathrm{Cr}$ & $<0.05$ & 0.012 & 0.010 & $<0.001$ & 0.040 \\
$\mathrm{Fe}$ & $<0.3$ & 0.240 & 0.490 & $<0.005$ & 2.630 \\
$\mathrm{P}$ & $<0.1$ & 0.530 & 2.650 & 0.020 & 14.570 \\
$\mathrm{Mn}$ & $<0.1$ & 0.030 & 0.020 & 0.010 & 0.090 \\
$\mathrm{Ti}$ & $<0.05$ & 0.009 & 0.010 & $<0.001$ & 0.040 \\
$\mathrm{Zn}$ & $<0.18$ & 0.360 & 0.270 & 0.100 & 0.990 \\
\hline
\end{tabular}

${ }^{a}$ All values adopted for this study were classified in the group of freshwaters in class 2, within the resolution No. 357-2005 of the National Council of the Environment (CONAMA). ${ }^{52}$ 
where a progressive decay of the content on the surface is observed, confirming the sedimentary adsorption process.

Concerning Zn, Labarrère et al. ${ }^{69}$ comment that this element accumulated in large quantities in the fish organism and is capable of causing histopathological changes in the gills such as hyperplasia, lamellar fusion, destruction of the epithelium, and excessive mucus production. In addition, $\mathrm{Zn}$ causes disturbances in the acid-base balance in several species of fish. Labarrère et al.$^{69}$ evaluated the effect of $\mathrm{Zn}$ on the behavior of fish (larvae of Chironomus sp.) and observed that exposure to this element is capable of causing a reduction in food consumption.

Authors ${ }^{70,71}$ state in their research that $\mathrm{Zn}$, as well as copper, $\mathrm{Fe}$, and $\mathrm{Ni}$, are essential for the aquatic environment in small quantities. They play a biochemical role and are needed as nutrients for vital processes in aquatic plants, animals, and microorganisms. However, in high concentrations, these trace chemical elements become toxic. In humans, the effects are related to prolonged excessive intake that can cause biochemical disturbances, such as inhibition of $\mathrm{Fe}$ and $\mathrm{Cu}$ absorption, causing nausea, vomiting, fever, fatigue, abdominal pain, skin irritation, and headache. ${ }^{72}$

Regarding the Fe element, it is pertinent to complement the discussion by citing research reports, ${ }^{73,74}$ to which it is commented that high concentrations of the metal can alter its sensory and organoleptic characteristics if it is consumed, in addition to benefiting Fe bacteria growth in water.

In the study, B was highlighted not for its average concentration but its variability. Statistically, levels above the standards established by CONAMA Resolution 357/05 were determined, ${ }^{52}$ indicating the existence of natural events acting in the environment, and the $B$ present in river waters originates from the weathering that occurs in hydrographic basins when it has content limestone rock, dolomites, and marlstones. ${ }^{75}$ Karro and Uppin ${ }^{76}$ reiterate the average concentrations of $\mathrm{B}$ in surface waters in aquifers in Estonia, which was $0.61 \mathrm{mg} \mathrm{L}^{-1}$, corroborating the observed values of this present study.

\section{Bivariate correlation}

This statistical method aimed to explain the existence of similarities between the variables shown in the descriptive statistics. The relevance of this information is associated with the possibility that the selected parameters have equivalent importance in terms of explaining the relevant environmental factors in the studied environment, attributing the test with significance levels between 95 and $99 \%$.

As the matrix presents parametric characteristics, Pearson's correlation was chosen to assess the existence of linear relationships between the variables, that is, when a chemical element directly influences another, as suggested by Castagné and Chadeau-Hyam. ${ }^{77}$

Table 3 shows that the most relevant linear interactions were between pairs $\mathrm{Al}$ and $\mathrm{B}$ (significance $(\mathrm{sig})<0.03$ ), $\mathrm{Al}$ and $\mathrm{Fe}$ (sig < 0.03), $\mathrm{Al}$ and $\mathrm{P}$ (sig < 0.05), $\mathrm{Al}$ and $\mathrm{Zn}(\mathrm{sig}<0.01), \mathrm{B}$ and $\mathrm{Ti}(\mathrm{sig}<0.04), \mathrm{Cr}$ and $\mathrm{Ti}$ (sig $<0.001)$, and $\mathrm{P}$ and $\mathrm{Zn}($ sig $<0.002)$.

Usually, the red mud retains all the $\mathrm{Fe}, \mathrm{Ti}$, and Si present in the bauxite, in addition to the $\mathrm{Al}$ that was not extracted during the refining, combined with the $\mathrm{Na}$ in the form of a hydrated silicate of $\mathrm{Al}$ and $\mathrm{Na}$ of a zeolitic nature. Additionally, oxides of $\mathrm{V}, \mathrm{Ga}, \mathrm{P}, \mathrm{B}, \mathrm{Mn}, \mathrm{Mg}, \mathrm{Zn}, \mathrm{Th}, \mathrm{Cr}$, and $\mathrm{Nb}$ may be present as trace elements. ${ }^{78}$

Regarding the consequences for human health, studies ${ }^{79}$ on surface waters in urban and industrial cities in West Bengal showed that the presence of elements such as $\mathrm{Zn}$ and $\mathrm{Al}$, among others, are the main contaminants responsible

Table 3. Bivariate Pearson correlation result between the elements

\begin{tabular}{|c|c|c|c|c|c|c|c|}
\hline & $\mathrm{Al}$ & B & $\mathrm{Cr}$ & $\mathrm{Fe}$ & $P$ & $\mathrm{Ti}$ & $\mathrm{Zn}$ \\
\hline \multirow{2}{*}{ B } & $0.680^{\mathrm{a}, \mathrm{b}}$ & 1 & & & & & \\
\hline & $0.031^{\mathrm{c}}$ & & & & & & \\
\hline \multirow{2}{*}{$\mathrm{Cr}$} & 0.189 & 0.608 & 1 & & & & \\
\hline & 0.601 & 0.062 & & & & & \\
\hline \multirow{2}{*}{$\mathrm{Fe}$} & 0.642 & 0.062 & -0.133 & 1 & & & \\
\hline & $0.044^{\mathrm{b}}$ & 0.864 & 0.714 & & & & \\
\hline \multirow[b]{2}{*}{$P$} & 0.719 & 0.476 & 0.044 & 0.382 & 1 & & \\
\hline & $0.054^{\mathrm{b}}$ & 0.165 & 0.903 & 0.276 & & & \\
\hline \multirow{2}{*}{$\mathrm{Ti}$} & 0.299 & $0.651^{b}$ & $0.957^{d}$ & -0.090 & 0.151 & 1 & \\
\hline & 0.402 & 0.042 & 0.001 & 0.805 & 0.678 & & \\
\hline \multirow{2}{*}{$\mathrm{Zn}$} & -0.723 & 0.318 & 0.121 & 0.360 & $0.846^{\mathrm{d}}$ & 0.097 & 1 \\
\hline & $0.012^{\mathrm{b}}$ & 0.370 & 0.740 & 0.306 & 0.002 & 0.789 & \\
\hline \multirow{2}{*}{ Mn } & -0.621 & -0.405 & -0.109 & 0.190 & -0.150 & -0.256 & 0.301 \\
\hline & 0.055 & 0.245 & 0.764 & 0.599 & 0.680 & 0.476 & 0.398 \\
\hline
\end{tabular}

${ }^{\mathrm{a}}$ Pearson correction values; ${ }^{\mathrm{b}}$ significant correlation at 0.05 level; ${ }^{\mathrm{c}}$ significance values; ${ }^{\mathrm{d}}$ significant correlation at 0.01 level. 
for polluting water bodies due to their easier integration in the biogeochemical cycle. They also report that to mitigate impacts, it is necessary to invest heavily to make it suitable for human purposes.

\section{Principal component analysis (PCA)}

The principal component analysis is employed to measure the importance of the original variables chosen, i.e., the original variables with the greatest weight in the linear combination of the first principal components, which are the most important from a statistical point of view. ${ }^{80}$

Analyzing the results of the univariate tests and using them as a basis to define the selection of variables in the multivariate method, it was possible to obtain the selection of descriptors capable of explaining the tested set with the minimum of lost information. This condition meant a reduction, after initial selection, from eight $(\mathrm{Al}, \mathrm{B}, \mathrm{Cr}$, $\mathrm{Fe}, \mathrm{Mn}, \mathrm{P}, \mathrm{Ti}$, and $\mathrm{Zn}$ ) to five variables ( $\mathrm{Al}, \mathrm{B}, \mathrm{Fe}, \mathrm{P}$, and $\mathrm{Zn}$ ) that stood out as the holders of a greater amount of information contained in the original matrix.

The variables Al (0.983), B (0.992), Fe (0.992), and $\mathrm{P}(0.991)$, were responsible for grouping the samples in principal component 1 (PC1) with a percentage of variance 79.24\%; the variable $\mathrm{Zn}$ (0.977) was responsible for grouping the samples in principal component 2 (PC2) with a percentage of $19.43 \%$, totaling an accumulated variance percentage of $98.68 \%$ (Tables 4 and 5).

The use of PCA as the main technique is to synthesize dispersed information in a diverse sample set. Some studies $^{81,82}$ argue that factor analysis is a widely accepted procedure for analysing independent variables, as it mainly rules out statistical redundancies.

According to Moura et al.,$^{80}$ the crossing between the first two components provides the location of the sample

(a)

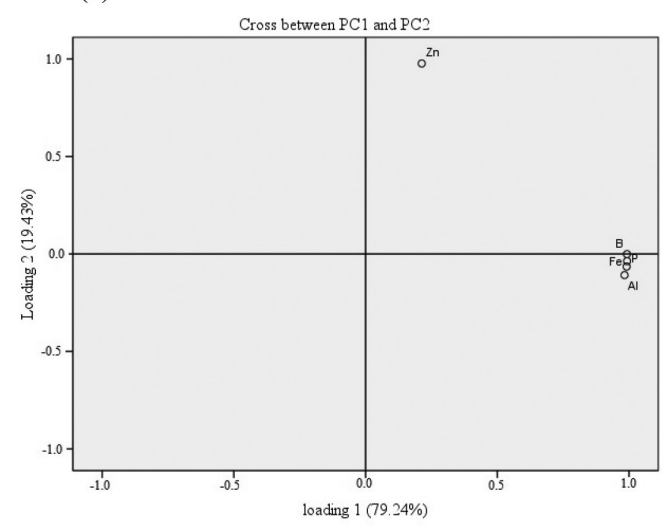

Table 4. Percentage of variances referring to the principal components

\begin{tabular}{lcc}
\hline Principal & \multicolumn{2}{c}{ Total variance / \% } \\
\cline { 2 - 3 } component & Partial variance & Accumulated variance \\
\hline 1 & 79.246 & 79.246 \\
2 & 19.437 & 98.683 \\
3 & 0.973 & 99.656 \\
4 & 0.312 & 99.968 \\
5 & 0.032 & 100.00 \\
\hline
\end{tabular}

Table 5. Principal component weights selected by PCA

\begin{tabular}{lcc}
\hline \multirow{2}{*}{ Variable } & \multicolumn{2}{c}{ Principal component } \\
\cline { 2 - 3 } & 1 & 2 \\
\hline $\mathrm{Al}$ & 0.983 & -0.109 \\
$\mathrm{~B}$ & 0.992 & -0.001 \\
$\mathrm{Fe}$ & 0.992 & -0.037 \\
$\mathrm{P}$ & 0.991 & -0.065 \\
$\mathrm{Zn}$ & 0.213 & 0.977 \\
\hline
\end{tabular}

influenced by the contribution of the original variables in each of the components plotted.

In Figure 5a, corresponding to the loadings, the behavior between the variables and the group of samples studied is illustrated and from this image is possible to confirm the formation of two groups. The first group consists of the elements $\mathrm{Al}, \mathrm{B}, \mathrm{Fe}$, and $\mathrm{P}$, and the second consists of $\mathrm{Zn}$ which is isolated from the others due to its prominence in the second principal component.

The explanation for the behavior of the element $\mathrm{Zn}$ comes from two aspects. The first is related to the results of the principal components since it stood out with the highest weight in the second component (Table 5) and thus being responsible for $19.43 \%$ of the information contained in the analyzed set. The second aspect is related to the metal content that stood out at collection point $9\left(0.999 \mathrm{mg} \mathrm{L}^{-1}\right)$

(b)

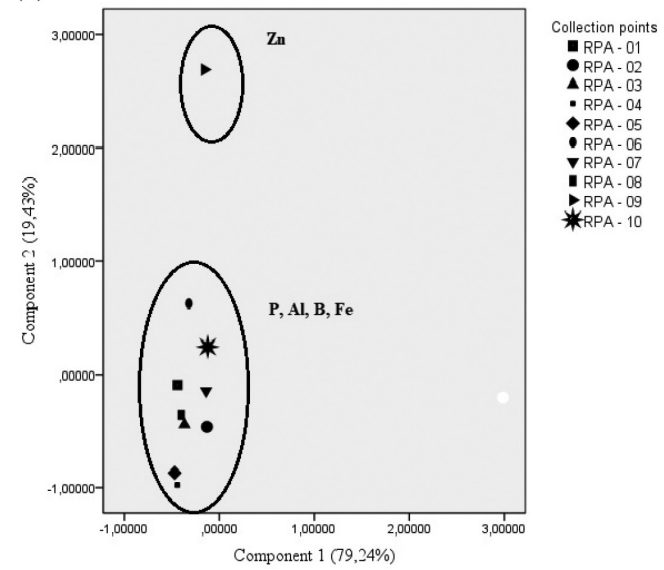

Figure 5. (a) Illustration of the crossing between the two PCAs according to the loads. (b) Illustration of the intersection between the two PCA according to the scores. 
as an anomalous sample within the data set. The probable justification for such anomalous condition may be associated with the proximity of discharge points of effluents from red mud, as explained by Matos et al. ${ }^{83}$ making it available environmentally in soluble form due to low levels of hardness that acts inversely proportional to the availability of metals, including zinc, as reported by Piratoba et al. ${ }^{84}$

In Figure 5b, corresponding to the scores, the grouping related to the samples is illustrated, and it can be observed at which points of collection the variables (chemical elements) had the greatest influence. According to the loadings graph, it was observed that the first component in which the aforementioned elements are present had a greater influence on samples 01, 02, 03, 04, 05, 06, 07, 08, and 10 as can be seen in the scores graph, whereas point 09 had $\mathrm{Zn}$ as the most influential metal.

Based on the results of variable selection by uni and multivariate methods, it was possible to categorize $\mathrm{Al}, \mathrm{B}$, $\mathrm{Fe}, \mathrm{P}$, and $\mathrm{Zn}$ as main PTEs. From them, it was possible to propose hydrodynamic models of toxic plumes with predictability indexes closer to the real condition.

\section{Hydrodynamic computational simulation model}

The Lagrangian transport model was adopted because it is suitable for simulating plumes of outfalls or effluent discharge points along a water body. ${ }^{47,82}$

For this study, the overflow situation of the red mud basins was simulated taking into account the moments of syzygy and quadrature of the rivers at a fixed point located at the exit of the tributary Furo do Arrozal (lat. $1^{\circ} 28^{\prime} 10.54$ ''S; long. $48^{\circ} 41^{\prime} 30.52^{\prime \prime} \mathrm{W}$ ) in the first tidal cycle, which corresponds approximately $13 \mathrm{~h}$ after launch. The choice of the site was because it is the main connection point between the Mucucupi and Barcarena rivers with the Pará River and, therefore, the most likely path for the red mud to travel.

Based on the statistical results, simulation scenarios were proposed in extreme conditions since the selected elements are above the limits established by the CONAMA resolution or present some risk.

Comparative scenario in extreme conditions between quadrature and syzygy for $1^{\text {st }}$ tidal cycle

The first scenario (Figure 6) refers to the quadrature or "dead tide" condition, $4 \mathrm{~h}$ after the release. In this situation, it was observed little mobility of the pollutants concerning the discharge point. This mobility can be explained by the fact that the admitted chemical elements present themselves in the ionic form $\mathrm{Al}^{3+}, \mathrm{B}^{3+}, \mathrm{Fe}^{2+}, \mathrm{PO}_{4}{ }^{3-}$, and $\mathrm{Zn}^{2+}$ in the water body, due mainly to the $\mathrm{pH}$ around 7 as reported by Piratoba et al ${ }^{.4}$
Such a statement is grounded in Pourbaix diagram analysis to which it is possible to identify the most probable form of a chemical element in an environment, as suggested by Fishtik. ${ }^{85}$ This information allows directing efforts to contain the plume to areas close to the source. Regarding the community service, the actions would concentrate on the communities located on the island of Trambioca. The other localities (São Sebastião da Boa Vista, Abaetetuba, Vila de Beja, Vila do Conde and Ponta de Pedras) demarcated on the map, at this time would enter a state of alert.

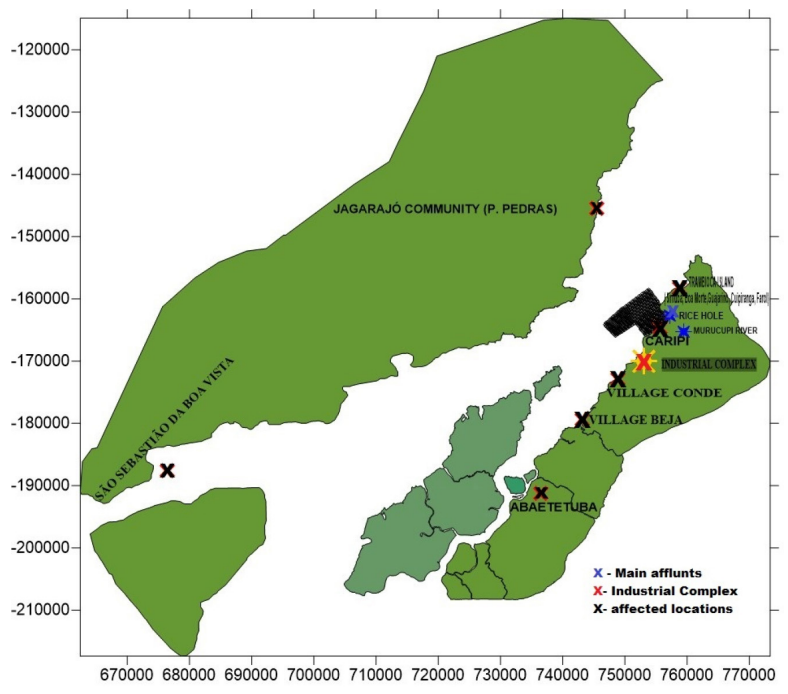

Figure 6. Simulated extreme scenario considering quadrature tide after $4 \mathrm{~h}$.

In the syzygy tide (Figure 7), there is a greater volume and flow of the water body, and taking into account this condition that occurred $10 \mathrm{~h}$ after discharge, was observed plume dispersion with greater intensity. This condition is related to the time when the river has the highest volume and flow. With the release occurring under this condition, the communities that need immediate support are the island of Trambioca and Furo do Arrozal, reaching the beach of Caripi, an important seaside resort located in the city of Barcarena, as demarcated on the map. It is valid to assume that this tidal condition, in the process of flooding and ebb tide, can reach the other localities highlighted on the map, should this situation be extended for a longer time.

Regarding the chemical elements listed, the main impacts are associated with the bioaccumulation process, since their solubility facilitates their entry into the food chain. According to Bjerknes et al. ${ }^{86}$ species such as Al can affect the ionic regulation and respiration of fish and when accumulated in humans can cause chronic changes in the body, skin problems, and in more serious cases changes in the central nervous system (CNS) causing Alzheimer's. ${ }^{87}$ About zinc, Lino et al.$^{88}$ considered an endogenous metal of essential characteristics with important biochemical 


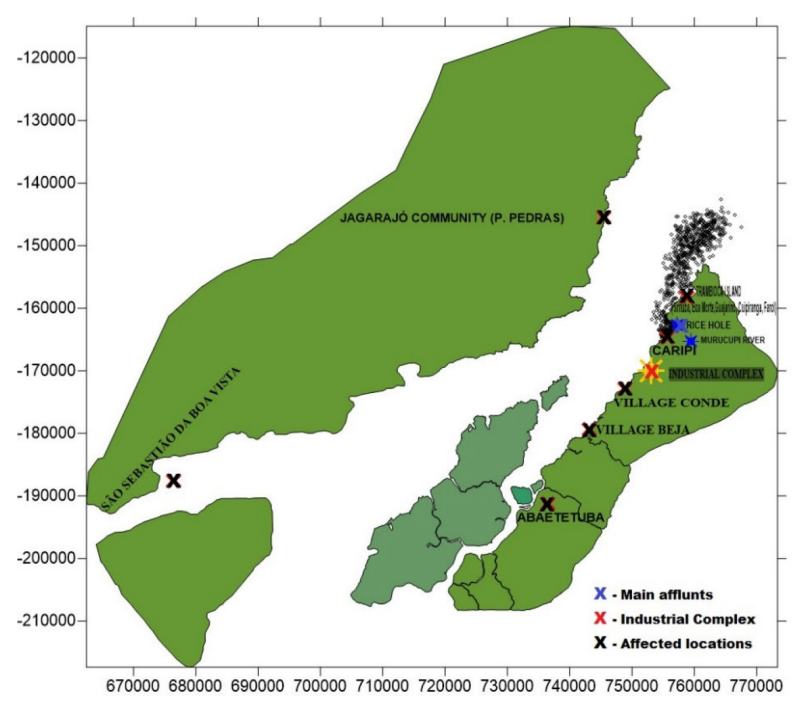

Figure 7. Simulated extreme scenario considering syzygy tide after $10 \mathrm{~h}$.

functions in the body, although its excessive absorption can cause several alterations in the human organism. The other elements $\mathrm{B}, \mathrm{Fe}$, and $\mathrm{P}$ are classified as essential and considered fundamental in the diet of human beings although the excess can cause pathological complications. ${ }^{89}$

The use of statistical techniques, especially principal component analysis, provided the study with a more detailed analysis for the analytical results, adding extremely relevant information through the selection of variables. For modeling pollution plumes such information was of great value since this information brought robustness to models that were selective and became specific, improving the predictive scenarios.

\section{Conclusions}

The integration of techniques in favor of scientific knowledge is of fundamental importance in view of technological advances and the need for high-precision information. It was in this sense that the study sought to integrate highly recognized analytical methods to propose viable solutions for forecasting and/or mitigating environmental events.

The univariate and multivariate statistical methods provided the study with a detailed view of this recurring problem in the Barcarena region. Using the technique, it was possible to identify that the elements aluminum, phosphorus, boron, and zinc as the chemical markers that present the greatest risks, when compared to CONAMA resolution No. 357/2005.

The simulation of scenarios using the SisBaHiA software has the function of presenting, through panoramas, the behavior of plumes in water bodies. The association of techniques allowed the implementation of realistic scenarios to which it became evident which are the toxic agents and the extent of their actions both to the environment and to the communities in the first $10 \mathrm{~h}$ after the event, with a high level of reliability. Models along these lines are of great value to society, as they assist in decision making for both rapid response agencies and the causative institutions.

In the situation proposed by the study, it was possible to identify that the mitigating and emergency actions, in the first $10 \mathrm{~h}$, should be directed to the communities of Trambioca and adjacent. This forecast guarantees quick responses from all the bodies and institutions involved, with advantages in saving time and related costs.

\section{Acknowledgments}

The authors thank the support of the Environmental Police Station of the Civil Police of the State of Pará, the Federal University of Pará, Amazon Foundation for Support to Studies and Research, for the funding of research, Observatory of the Amazon Coast and Physical Oceanography Laboratory, from the Geosciences Institute of the Federal University of Pará, for its support in providing hydrodynamic information.

\section{Author Contributions}

Pedro M. de Sousa Jr. was responsible for investigation, writing original draft, data curation, writing-review and editing, sample collection; Simone F. P. Pereira for conceptualization, formal analysis, funding acquisition, project administration, resources, sample collection; Ronaldo M. Rocha for chemical analysis, funding acquisition, resources; Mateus H. D. Alves for writingreview and editing; Luciana $\mathrm{S}$. Pinheiro for sample collection and editing; Daniel P. Nogueira for project administration, sample collection; Orivan M. M. Teixeira for sample collection and chemical analysis; Auriane C. S. Gonçalves for sample collection and editing.

\section{References}

1. Rakotondrabe, F.; Ngoupayou, J. R. N.; Mfonka, Z.; Rasolomanana, E. H.; Abolo, A. J. N.; Ako, A. A.; Sci. Total Environ. 2018, 610, 831.

2. Bingöl, D.; Ay, Ü.; Bozbaş, S. K.; Uzgören, N.; Mar. Pollut. Bull. 2013, 68, 134.

3. Gomes, M. E. P.; Antunes, I. M. H. R.; Silva, P. B.; Neiva, A. M. R.; Pacheco, F. A. L.; J. Geochem. Explor. 2010, 105, 153.

4. Bhardwaj, R.; Gupta, A.; Garg, J. K.; Water Sci. 2017, 31, 52.

5. Saha, N.; Rahman, M. S.; Environ. Nanotechnol. Monit. Manage. 2018, 10, 206. 
6. Henriques, A. B.; Porto, M. F. S.; Cien. Saude Colet. 2013, 18 , 3223.

7. Carmo, M. B. S.; Costa, S. M. F.; Rev. Bras. Gest. Urbana 2016, 8, 291.

8. Zacháry, D.; Jordan, G.; Völgyesi, P.; Bartha, A.; Szabó, C.; J. Geochem. Explor. 2015, 158, 186.

9. Arifin, M. H.; Kayode, J. S.; Ismail, M. K. I.; Abdullah, A. M.; Embrandiri, A.; Nazer, N. S. M.; Azmi, A.; J. Hazard. Mater. 2020, 124282.

10. Kumar, M.; Ramanathan, A. L.; Tripathi, R.; Farswan, S.; Kumar, D.; Bhattacharya, P.; Chemosphere 2017, 166, 135.

11. Hou, D.; O'Connor, D.; Nathanail, P.; Tian, L.; Ma, Y.; Environ. Pollut. 2017, 231, 1188.

12. Jha, D. K.; Ratnam, K.; Rajaguru, S.; Dharani, G.; Prashanthi Devi, M.; Kirubagaran, R.; Mar. Pollut. Bull. 2019, 146, 1.

13. Singh, G.; Rishi, M. S.; Herojeet, R.; Kaur, L.; Priyanka; Sharma, K.; J. Geochem. Explor. 2020, 208, 106395.

14. Tonhá, M. S.; Araújo, D. F.; Araújo, R.; Cunha, B.C. A.; Machado, W.; Portela, J. F.; Souza, J. P. R.; Carvalho, H. K.; Dantas, E. L.; Roig, H. L.; Seyler, P.; Garnier, J.; J. Environ. Sci. 2021, 101, 313.

15. Bodrud-Doza, Md.; Towfiqul Islam, A. R. M.; Ahmed, F.; Das, S.; Saha, N.; Rahman, M. S.; Water Sci. 2016, 30, 19.

16. Islam, A. R. M. T.; Shen, S.; Haque, M. A.; Bodrud-Doza, Md.; Maw, K. W.; Habib, Md. A.; Environ. Sustainable Dev. 2018, 20, 1935.

17. Periáñez, R.; Environ. Pollut. 2005, 133, 351.

18. Oprea, M.; Environ. Model. Softw. 2018, 110, 72.

19. Pereira, S. F.; de Lima, M. A.; Freitas, K. H.; Mescouto, C. S.; Saraiva, A. F.; Rev. Ambient. Água 2007, 2, 62.

20. Rodrigues, H. C. T.; da Silva Campos, P. S.; Almeida, H. F. P.; Paiva, P. F. P. R.; dos Santos Jr., P. C.; Marques, G. T.; Morais, E. C.; Soares, J. A. C.; Almeida, J. F. S.; Chase, O. A.; Braz. J. Dev. 2020, 6, 1598.

21. Instituto Evandro Chagas (IEC/SVS/MS); Avaliação dos Impactos Ambientais Referente ao Transbordo e Lançamentos Irregulares de Efluentes de Lama Vermelha na Cidade de Barcarena, Estado do Pará; 2018, available at https://www. iec.gov.br/wp-content/uploads/2018/03/RELAT\%C3\%93RIOT\%C3\%89CNICO-003-2018-Final-Tabelas-Modificadas-SS-1. pdf, accessed in June 2021.

22. Vieira, A. S. A.; Crispim, D. L.; Rodrigues, R. S. S.; Silva, I. Q.; Pessoa, F. C. L.; Geonorte 2018, 9, 67.

23. Krishna, A. K.; Satyanarayanan, M.; Govil, P. K.; J. Hazard. Mater. 2009, 167, 366.

24. GPS TrackMaker ${ }^{\circledR}$ Free, version 13.9.596; available at https:// www.trackmaker.com/main/pt/download-gps-software-gratis, accessed in May 2019.

25. Google Earth Pro; available at www.google.com.br/intl/pt-BR/ earth/, accessed in May 2019.

26. American Public Health Association (APHA); Standard Methods for the Examination of Water and Wastewater, $21^{\text {th }}$ ed.;
American Public Health Association (APHA/AWWA/WEF): Washington, 2005.

27. Companhia Ambiental do Estado de São Paulo (CETESB); Guia Nacional de Coleta e Preservação de Amostras: Água, Sedimento, Comunidades Aquáticas e Efluentes Líquidos; CETESB/ANA: Brasília, 2011, p. 327, available at https:// arquivos.ana.gov.br/institucional/sge/CEDOC/Catalogo/2012/ GuiaNacionalDeColeta.pdf, accessed on February 26, 2020.

28. Boss, C. B.; Freeden, K. J.; Concepts, Instrumentation and Techniques in Inductively Coupled Plasma Optical Emission Spectrometry; PerkinElmer Corp.: USA, 1997.

29. U.S. EPA Method 6010D (SW-846): Inductively Coupled Plasma-Atomic Emission Spectrometry, Revision 4; Washington, DC, 2014.

30. IBM SPSS Statistics 21; IBM, New Orchard Road Armonk, New York, USA, 2012, available at http://www-01.ibm.com/ software/analytics/spss/products/statistics, accessed in June 2021.

31. Dillon, W. R.; Goldstein, M.; Multivariate Analysis: Methods and Applications; Wiley: New York, USA, 1984.

32. Guedes, H. A.; Silva, D. D. D.; Elesbon, A. A.; Ribeiro, C.; Matos, A. T. D.; Soares, J. H.; Rev. Bras. Eng. Agríc. Ambient. 2012, 16, 558.

33. Brereton, R. G.; Applied Chemometrics for Scientists; John Wiley \& Sons Ltd: West Sussex, England, 2007.

34. Wang, X.; Liu, L.; Zhao, L.; Xu, H.; Zhang, X.; Mar. Pollut. Bull. 2019, 149, 110608.

35. Küchler, I. L.; Miekeley, N.; Forsberg, B. R.; J. Braz. Chem. Soc. 2000, 11, 286.

36. Rocha, C. H. B.; Pereira, A. M.; Rev. Ambient. Água 2016, 11, 176.

37. Ustaoğlu, F.; Tepe, Y.; Int. Soil Water Conserv. Res. 2019, 7, 47.

38. Ramin, M.; Labencki, T.; Boyd, D.; Trolle, D.; Arhonditsis, G. B.; Ecol. Model. 2012, 242, 127.

39. Sadegh, M.; Moftakhari, H.; Gupta, H. V.; Ragno, E.; Mazdiyasni, O.; Sanders, B.; Matthew, R.; AghaKouchak, A.; Geophys. Res. Lett. 2018, 45, 5470.

40. Moftakhari, H.; Schubert, J. E.; AghaKouchak, A.; Matthew, R. A.; Sanders, B. F.; Adv. Water Resour. 2019, 128, 28.

41. Shahat, M. F.; Sadek, M. A.; Salem, W. M.; Embaby, A. A.; Mohamed, F. A.; J. Water Health 2017, 15, 644.

42. Seigneur, C.; Roth, P. M.; Wyzga, R. E. In NATO · Challenges of Modern Society; Springer: Boston, USA, 1983.

43. Mastrocicco, M.; Colombani, N.; Sbarbati, C.; Petitta, M.; Water, Air, Soil Pollut. 2012, 223, 4417.

44. Devlin, M. J.; Harkness, P.; McKinna, L.; Abbott, B. N.; Brodie, J.; Mar. Pollut. Bull. 2012, 65, 224.

45. Lardner, R.; Zodiatis, G.; Mar. Pollut. Bull. 2017, 124, 94.

46. Premathilake, L.; Khangaonkar, T.; Mar. Pollut. Bull. 2019, 149,110554 
47. Rosman, P. C. C.; SisBaHiA - Sistema Base de Hidrodinâmica Ambiental, v.1.0; Instituto Alberto Luiz Coimbra de Pós-Graduação e Pesquisa de Engenharia/UFRJ, Brazil, 2015, available at www.sisbahia.coppe.ufrj.br/, accessed on March 10, 2019.

48. Harari, J.; Ferreira, F. R.; Degaspari, F. A.; Sartor, S. M.; Rev Bras. Recur. Hídricos 2013, 18, 205.

49. Yang, S. H.; Harari, J.; Braga, E. S.; Eng. Sanit. Ambient. 2019, 24, 697.

50. Centro de Hidrografia da Marinha, https://www.marinha.mil.br/ chm/dados-do-segnav-cartas-raster/de-mosqueiro-abaetetuba, accessed in June 2021.

51. Fundação de Estudos do Mar (FEMAR); Catálogo de Estações Maregráficas Brasileiras; FEMAR: Rio de Janeiro, 2000.

52. Conselho Nacional de Meio Ambiente (CONAMA); Resolução No. 357, de 17 de março de 2005, Dispõe sobre A Classificação dos Corpos de Água e Diretrizes Ambientais para o seu Enquadramento, bem como Estabelece as Condições e Padrões de Lançamento de Efluentes, e Dá Outras Providências, Diário Oficial União (DOU), Brasília, No. 053, de 18/03/2005, p. 58.

53. Graham, J. A.; Haverson, D.; Bacon, J.; Mar. Pollut. Bull. 2020, $150,110589$.

54. Silva, L. G.; da Silva, G. E. D. L.; da Silva, A. B.; de Souza Menezes, R.; Braz. J. Dev. 2020, 6, 4649.

55. https://oca.eco.br/pt_br/banco-de-dados/, accessed in June 2019.

56. Harrar, S. W.; Feyasa, M. B.; Wencheko, E.; Comput. Statist. Data Anal. 2020, 144, 106903.

57. Horváth, L.; Kokoszka, P.; Wang, S.; J. Multivar. Anal. 2020 , 179, 104640.

58. Rachdi, M.; Laksaci, A.; Al-Awadhi, F. A.; Spat. Stat. 2021, 43, 100498.

59. Lima, W. N.; Kobayasbi, C. N.; Geochim. Bras. 2011, 1, 53.

60. Brown, R. C.; Lockwood, A. H.; Sonawane, B. R.; Environ. Health Perspect. 2005, 113, 1250.

61. Exley, C.; J. Alzheimer's Dis. 2006, 10, 173.

62. Guibaud, G.; Gauthier, C.; J. Inorg. Biochem. 2003, 97, 16.

63. D'Haese, P. C.; Douglas, G.; Verhulst, A.; Neven, E.; Behets, G. J.; Vervaet, B. A.; Finsterle, K.; Lürling, M.; Spears, B.; Chemosphere 2019, 220, 286.

64. Pratt, C.; Shilton, A.; Pratt, S.; Haverkamp, R. G.; Elmetri, I.; Environ. Sci. Technol. 2007, 41, 6585.

65. Wu, Y.; Wen, Y.; Zhou, J.; Wu, Y.; KSCE J. Civ. Eng. 2014, 18, 323.

66. Yuan, S.; Tang, H.; Xiao, Y.; Xia, Y.; Melching, C.; Li, Z.; J. Hydrol. 2019, 573, 568.

67. Tang, H.; Zhang, H.; Yuan, S.; Environ. Fluid Mech. 2018, 18, 443.

68. Instituto Nacional de Meteorologia (INMET); Estação Meteorológica de Observação de Superfície Automática, Brasília, DF, Brazil, available at https://portal.inmet.gov.br/ dadoshistoricos, accessed in April 2020.
69. Labarrère, C. R.; Menezes, B. D.; Melo, M. M.; Geonomos 2012, 20, 86.

70. Goher, M. E.; Farhat, H. I.; Abdo, M. H.; Salem, S. G.; Egypt. J. Aquat. Res. 2014, 40, 213.

71. Goher, M. E.; Ali, M. H.; El-Sayed, S. M.; Egypt. J. Aquat. Res. 2019, 45, 301.

72. Liu, M.; Xu, Y.; Nawab, J.; Rahman, Z.; Khan, S.; Idress, M.; Ud din, Z.; Ali, A.; Ahmad, R.; Khan, S. A.; Khan, A.; Khan, M. Q.; Tang, Y. T.; Li, G.; Environ. Technol. Innovation 2020, 17, 100554.

73. Yagoub, S. O.; Ahmed, R. Y.; Res. J. Microbiol. 2009, 4, 355.

74. Rahman, M. A.; Hashem, M. A.; Phys. Chem. Earth, Parts $A / B / C$ 2019, 109, 49.

75. Kuliński, K.; Szymczycha, B.; Koziorowska, K.; Hammer, K.; Schneider, B.; Mar. Chem. 2018, 204, 11.

76. Karro, E.; Uppin, M.; Environ. Monit. Assess. 2013, 185, 3735.

77. Castagné, R.; Chadeau-Hyam, M. In The Handbook of Metabolic Phenotyping; Lindon, J. C.; Nicholson, J. K.; Holmes, E., eds.; Elsevier: Amsterdam, Oxford, Cambridge, 2019, p. 237.

78. Santona, L.; Castaldi, P.; Melis, P.; J. Hazard. Mater. 2006, 136, 324.

79. Saha, P.; Paul, B.; Hum. Ecol. Risk Assess. 2019, 25, 966.

80. Moura, M. C. S. D.; Lopes, A. N. C.; Moita, G. C.; Moita Neto, J. M.; Quim. Nova 2006, 29, 429.

81. Karkra, R.; Kumar, P.; Ks, B.; Krishna, C. R.; Procedia Comput. Sci. 2016, 93, 988.

82. Tripathi, M.; Singal, S. K.; Ecol. Indic. 2019, 96, 430.

83. Matos, A. C. S.; Teixeira, R. R. C.; Tavares, F. B.; da Silva Lima, I.; Andrade, A. L. C.; de Azevedo, L. E. C.; Farrinelli, G. F. B.; Braz. J. Dev. 2020, 6, 29644.

84. Piratoba, A. R. A.; Ribeiro, H. M. C.; Morales, G. P.; Gonçalves, W. G.; Rev. Ambient. Água 2017, 12, 435.

85. Fishtik, I.; Environ. Sci. Technol. 2006, 40, 1902.

86. Bjerknes, V.; Fyllingen, I.; Holtet, L.; Teien, H. C.; Rosseland, B. O.; Kroglund, F.; Mar. Chem. 2003, 83, 169.

87. Walton, J. R. In Encyclopedia of Environmental Health; Nriagu, J. O., ed.; Elsevier: Burlington, 2011, p. 331.

88. Lino, A. S.; Kasper, D.; Silva, A. L. A. D.; Teixeira, B. D. S.; Thomaz, J. R.; Carvalho, G. O. D.; Malm, O.; Orbital: Electron. J. Chem. 2018, 10, 272.

89. Russell, R. M.; Beard, J. L.; Cousins, R. J.; Dunn, J. T.; Ferland, G.; Hambidge, K. M.; Lynch, S.; Penland, J. G.; Ross, A. C.; Stoecker, B. J.; Suttie, J. W.; Turnlund, J. R.; West, K. P.; Zlotkin, S. H.; Munro, I. C.; Murphy, S. P.; Young, V. R.; Trumbo, P. R.; Yates, A. A.; Dietary Reference Intakes for Vitamin A, Vitamin K, Arsenic, Boron, Chromium, Copper, Iodine, Iron, Manganese, Molybdenum, Nickel, Silicon, Vanadium, and Zinc; The National Academies Press: Washington, DC, 2001.

Submitted: January 15, 2021

Published online: June 23, 2021 